\title{
Urbanisation, Sustainable Growth and Poverty Reduction in Asia
}

\section{Malcolm Jack}

\section{Context \\ 1.1 Urbanisation trends in Asia}

Almost 3 billion people live in urban areas across the world - equivalent to 48 per cent of the world's total population. Asia accounts for almost half of these, with an urban population of between 1.3 and 1.5 billion people, accounting for approximately 37 per cent of Asia's total population (UN-Habitat 2003a; ACHR 2005). These statistics for Asia are perhaps conservative, as different countries define 'urban centres' differently, based upon both population size and other criteria. If either India or China were to redefine their criteria to include some smaller settlements as 'urban', then an even greater proportion of Asia's population would be considered 'urban' (Satterthwaite 2005).

Asia has a fast-growing urban population. The urban population in the region as a whole is projected to grow to 1.8 billion by 2010 (see Figure 1), and as a result Asia is expected to account for a growing proportion of the world's urban population - just over 50 per cent by 2010 (see Figures 2 and 3). The UN expects this number to increase to between 53 per cent and 55 per cent of the world's urban population by 2030 (UN-Habitat 2004).
In addition to a growing urban population, Asia is also urbanising - that is a growing proportion of its total population live in urban areas (see Figure 4). There are three potential factors contributing to this urbanisation trend, which have varying impacts in different countries:

- Net inward migration to urban areas - more people move from rural to urban areas than from urban to rural areas

- Natural population growth is higher in urban areas than in rural areas

- Reclassification of rural settlements as urban settlements.

The first of these is a significant factor in most Asian countries - migration patterns, and their relationship to economic development patterns, are examined in the next section. The second factor is rarer, although present in countries such as Indonesia and the Philippines. Around one-third of Indonesia's urbanisation is explained by higher rates of natural population growth in urban areas than in rural areas, a third by reclassification and the remainder by net rural-urban migration. Urbanisation in the Philippines is also driven partly by high rates of natural increase

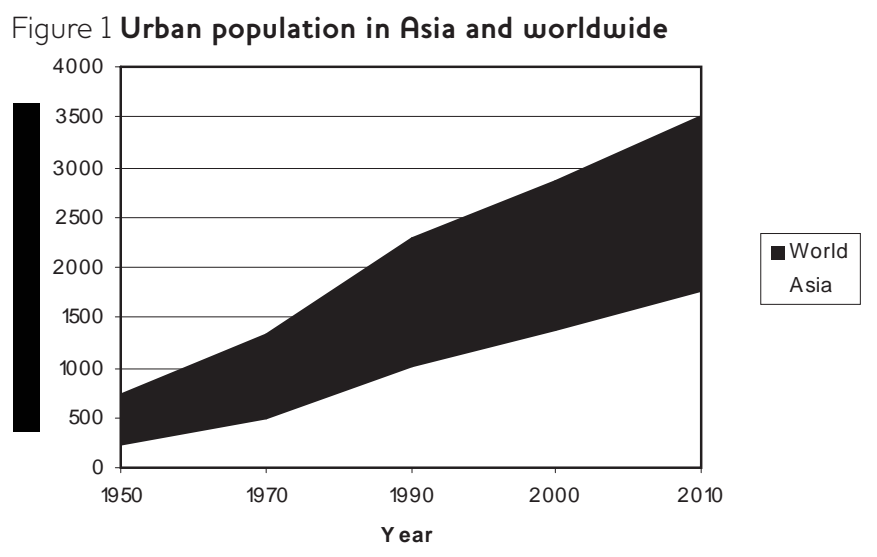

IDS Bulletin Volume 37 Number 3 May 2006 (c) Institute of Development Studies 


\section{Figure 2 Urban population trends $1950-2010$ by continent/region}
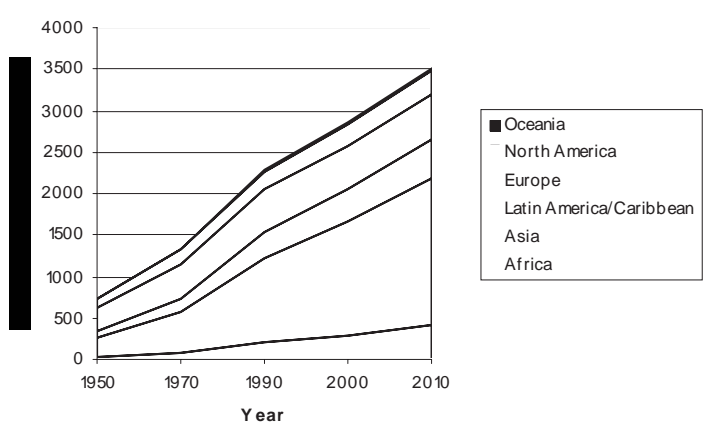

Figure 3 Projected distribution of the world's urban population in 2010 by continent/region

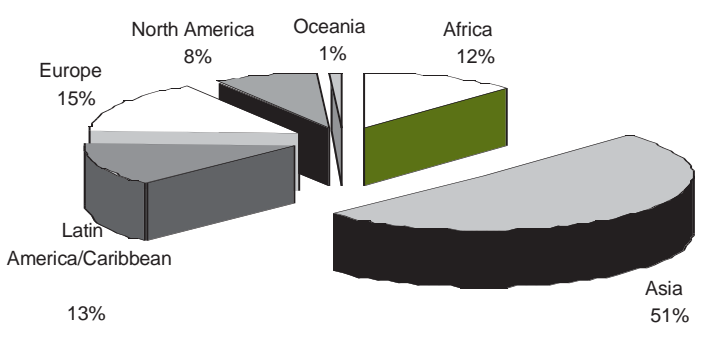

in urban populations, and partly by migration patterns (Webster 2004). The third factor is noticeable in countries including China, Indonesia, Vietnam and Thailand, as cities grow outwards and 'envelop' relatively populous rural areas.

The regional trend towards increasingly rapid urbanisation is reflected in most Asian countries. The fact that five of Asia's six most populous countries demonstrate these trends is particularly significant (see Figure 5). Having begun the 1970s with less than 25 per cent of their populations living in urban areas, China, India, Indonesia, Bangladesh and Pakistan have urbanised rapidly and consistently over the last 30 years, and all are projected to continue doing so over at least the next two decades. China alone will gain 425 million additional urban dwellers over the next three decades. The sixth country, Japan, has urbanised at a much lower rate having begun the 1970s with more than 70 per cent of its population already living in urban areas.

During the same period, Mongolia and Malaysia have urbanised to the extent that more than 60 per cent of their populations currently live in urban areas, with these figures projected to rise beyond 70 per
Figure 4 Urbanisation trend in Asia 1950-2010

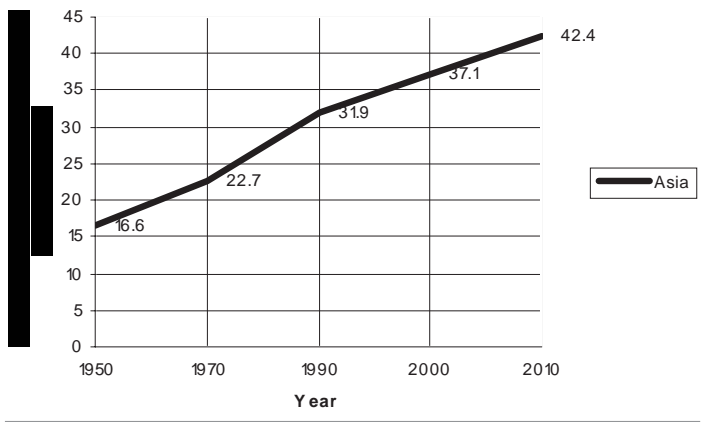

cent by 2030. The Philippines is also expected to surpass the 70 per cent mark by 2030. A cluster of other Asian countries have begun to urbanise more rapidly over the last 5-10 years, and projections suggest that their rates of urbanisation will also increase over the next two decades, albeit at a lower trajectory than Mongolia, Malaysia and the Philippines (see Figure 6).

By 2000, Asia had more than half of the world's largest cities, including ten 'mega-cities' (with populations in excess of 10 million). Two of these were in China, two in Japan, three in India, one in Indonesia, one in Bangladesh and one in Pakistan. By 2015, Asia is expected to have 12 mega-cities, with the addition of Metro Manila in the Philippines and Tianjin in China. The number of Asian cities with more than 5 million people is also projected to grow. There were nine in 1975, 21 in 2000 and 36 are projected for 2015. By 2000, Asia also held 194 of the world's 387 cities with a population of 1 million or more, and accounted for 44 of the world's 100 largest cities.

Aggregate country-level statistics for the levels of urbanisation and the rates of urbanisation can, however, mask different sub-national trends. There are various dimensions of urbanisation affecting Asia's urban centres. These include:

- Numerous examples of large Asian touns and cities that have grown rapidly and extensively: taking 'annual average increment in population 1950-2000' as an indicator of urban growth, eight of the world's ten fastest growing cities were in Asia (Tokyo, Mumbai, Delhi, Dhaka, Jakarta, Karachi, Seoul and Kolkatta)

- Other large, medium and small urban areas with 'large annual percentage increases in population': 


\section{Figure 5 Urbanisation trends in Asia's six most populous countries}

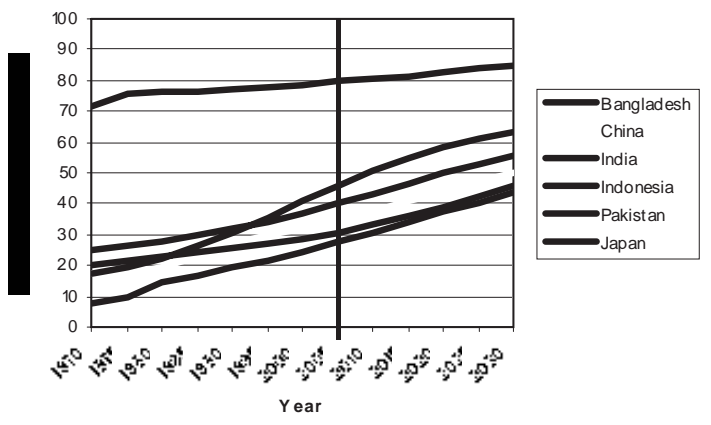

between 1975 and 2000, six of the world's 11 fastest growing cities were in Asia (Chittagong, Dhaka, Riyadh, Kabul, Jidda and Surat in India) experienced population growth in excess of 5 per cent per year

- Significant numbers of fast-growing Asian cities projected in future: between 2000 and 2015, Asia is projected to account for 14 of the world's 19 fastest growing urban centres (in terms of annual percentage increases in population), whose population will more than double in 15 years: five in China, four in South Korea, two in India, and one each in Yemen, Nepal and Iran'

- Urban population highly concentrated in a single urban centre in some countries: the degree of 'city primacy', as this is known, is crudely calculated as the proportion of a country's total urban population living in the urban centre in question. By 2000, Thailand (Bangkok), Afghanistan (Kabul), Mongolia (Ulan Bator) and Cambodia (Phnom Penh) particularly exhibited this feature, in addition to the city-states of Hong Kong and Singapore. Of these four, only Cambodia is projected to change this status by 2015 (UN Population Division 2002)

- Significant variations in growth rates between urban areas in the same country, for example in Mongolia and China.

Although further work is required to better project the exact magnitude of future urbanisation trends in Asia, and aggregate national statistics may mask fluctuating dynamics in different urban centres, the broad trend of increasing urbanisation is well established. The growing scale of urbanisation, the rapid pace of urbanisation, the sheer numbers of people living in urban areas and the fact that these trends affect a large number of Asian countries,

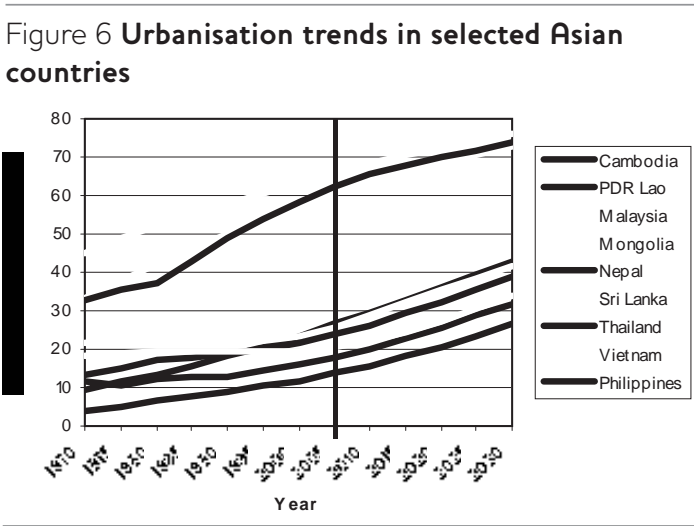

demands a closer inspection of the key development challenges and associated policy implications.

\subsection{The interrelationship between urbanisation and economic development}

'Urbanisation rates are strongly correlated with per capita income, productivity tends to be high in cities, and urban job creation is an important driver of economic growth ... The performance of the urban sector bears on overall economic growth'. (Overman and Venables 2005: 1)

Urban areas account for as much as 70 per cent of gross domestic product (GDP) growth in East Asia. In the Philippines, urban areas account for 75-80 per cent of gross national product (GNP) and 80 per cent of its economic growth. Vietnam's urban areas contribute 70 per cent of the country's economic growth (Webster 2004). In South Asia, Mumbai on its own is estimated to generate one-sixth of India's GDP (Sierra 2005: 29). The industrial and service sectors contribute an increasing amount to national GDP - more than half in most Asian countries. These sectors are generally located in urban areas, due to a mixture of larger concentrations of inputs (materials, labour, infrastructure and services); larger concentrations of consumers (the 'market'); greater opportunities for networking and rapid knowledge sharing; proximity to administrative institutions who regulate commercial activity; and other economies of scale and scope. Globalisation, urbanisation and other sociopolitical factors have also heightened the dynamic economic links between cities and their surrounding peri-urban and rural areas (RodríguezPose 2004).

In general, the more rapid a country's economic growth, the faster it urbanises - urbanisation both 
Figure 7 The different aspects of urban poverty

1 Inadequate income (and thus inadequate consumption of necessities including food and, often, safe and sufficient water; often problems of indebtedness, with debt repayments significantly reducing income available for necessities).

2 Inadequate, unstable or risky asset base (non-material and material including educational attainment and housing) for individuals, households or communities.

3 Inadequate shelter (typically poor quality, overcrowded and insecure).

4 Inadequate provision of 'public' infrastructure (piped water, sanitation, drainage, roads, footpaths etc.) which increases the health burden and often the work burden.

5 Inadequate provision of basic services such as day care/schools/vocational training, healthcare, emergency services, public transport, communications, law enforcement.

6 Limited or no safety net to ensure basic consumption can be maintained when income falls; also to ensure access to shelter and healthcare when these can no longer be paid for.

7 Inadequate protection of poorer groups' rights through the operation of the law including laws and regulations regarding civil and political rights, occupational health and safety, pollution control environmental health, protection from violence and other crimes, protection from discrimination and exploitation.

8 Poorer groups' voicelessness and powerlessness within political systems and bureaucratic structures, leading to little or no possibility of receiving entitlements; of organising, making demands and getting a fair response; and of receiving support for developing their own initiatives. Also, no means of ensuring accountability from aid agencies, NGOs, public agencies and private utilities and being able to participate in the definition and implementation of their urban poverty programmes.

Satterthwaite (2002: 3).

reflects, and contributes to, economic growth and economic development patterns. The increasing numbers and proportions of the population living in urban areas in most Asian countries reflects a growing concentration of people, and their families, seeking to take advantage of the increased demand for labour in the industrial and service sectors. ${ }^{2}$

'Cities grow as private investment concentrates there. But there is no automatic development of any capacity to govern the city and ensure that growing populations and economic activities can get the land, infrastructure and services they need. Cities may concentrate wealth, both in terms of new investment and of high-income residents, but there is no automatic process by which this contributes to the costs of needed infrastructure and services... All cities and most smaller urban centres face a contradiction between what drives their economic development (and the in-migration this generates) and what contributes to adequate accommodation for the workforce on which they depend'. (ACHR 2005: 5)

Sustainable urbanisation will underpin Asia's economic growth and development, but also presents several major challenges. The magnitude and priority of these issues vary from country to country, but they generally include: 
- Finding a balance between commercial, residential and public land use, in a context of increased competition for urban land

- Ensuring adequate provision of shelter and secure tenure for all residents, particularly the lowincome workforce who are integral to the city economy

- Providing basic infrastructure (e.g. water, sanitation, electricity, drainage, access) on which residents and productive enterprise depend

- Ensuring adequate provision of social services (e.g. health, education, law enforcement) to all residents

- Ensuring residents' incomes are adequate to meet the higher costs of goods and services in urban areas

- Ensuring adequate transport infrastructure, taking into account the impact of pollution associated with increased road use

- Dealing with poverty and exclusion issues, which reflect some of the issues described above.

\subsection{The nature of poverty and exclusion in urban areas}

There are often arguments about how to define and how to measure poverty and exclusion in urban areas. In Figure 7 Satterthwaite (2002: 3) lists eight aspects of urban poverty, which are helpful in considering issues of exclusion and the appropriate range of possible policy responses, and also how urbanisation may relate to each aspect. Figure 7 should not be taken as a hierarchy of issues, and some aspects can be interrelated.

Income-based poverty lines are often set too low in relation to higher costs of 'non-food essentials' in many urban areas (including housing, water, other goods and services). 'There are [therefore] good grounds for suggesting that the scale of urban poverty is systematically under-estimated in the official statistics produced and used by governments and international agencies' (Satterthwaite 2004: 1). Urbanisation is usually correlated with job creation, although some of this occurs in the informal sector. While the informal sector plays a vital role in many of Asia's urban areas (both in terms of supporting economic growth and providing income-earning opportunities for the urban poor), it can also mean that people are compelled to work in unhealthy and/or unsafe conditions. Unemployment figures for urban areas are also difficult to determine because many work in the informal sector. The mix of permanent, semi-permanent and seasonal migrant workers also makes measurement difficult. It has however been noted that despite national trends towards older populations in most Asian countries, urban areas are expected to account for increasing proportions of young people (Gubhaju et al. 2001). Strategies to improve incomes, employment opportunities and working conditions will need to take this into account.

Informal 'slum' settlements, and other forms of 'under-served' settlements, ${ }^{3}$ are the most obvious physical manifestation of the contradiction between the demand for labour in Asia's urban areas on the one hand, and inadequate provision for affordable housing, land and infrastructure in which they and their families can live safely on the other. Furthermore, slums often demonstrate a concentration of multiple deprivations experienced by the urban poor (UN Millennium Project 2005a). Some 900 million people live in slums worldwide. Asia contains most of them - around 60 per cent at present. By 2001, between 550 and 570 million people lived in slums and informal settlements within Asia as a whole, having grown from 420 million in 1990 (UN-Habitat 2003b; UN-Habitat 2005: 35; DFID 2004). That is, at least one in three (33 per cent) of Asia's urban population do not have safe and secure housing and are largely excluded from achieving their political, social and economic rights. In South Asia, this figure rises to 58 per cent. The number of people living in slums in Asia is projected to grow fast - reaching 839 million by 2020 (UNHabitat 2003a). As such, slum dwellers constitute a major vote bank within many Asian countries.

Access to land highlights the contradictions that can arise from urban growth and economic development in urban areas, and is a major determinant of the quality of shelter available to Asia's urban poor. As more and more financial investment and people flow into Asia's urban areas, demand for land has increased. As a result, land is increasingly viewed as a valuable commodity which can be sold for commercial development or middle-class residential use. Large-scale infrastructure projects also place demands upon land, often requiring the relocation of informal settlements and the people who live in them. The poor are least able to access or secure land in this context, both for financial reasons and because formal systems do not recognise their often informal contributions to city life. The urban poor are 
frequently forced to live on marginal/hazardous land and/or in locations which are distant from places of work, services and often poorly served by public transport. The threat of eviction limits people's willingness to further invest in housing and infrastructure, and can lead to psychological pressures from fear and uncertainty. In South Asia alone, more than 150 million people lack secure tenure in urban areas, leaving them open to the threat of eviction. In this situation, it is increasingly difficult for poor people to effectively supply their labour or participate in cities' economic growth and development (ACHR 2003b: 2).

Because many of the urban poor are forced to live on marginal land, in unsafe environments and in poor-quality housing, they are particularly vulnerable to natural disasters. They are also least able to withstand external shocks compared with the rest of the urban population, due to an inadequate asset base and/or social and financial safety nets. This vulnerability applies as much to withstanding and recovering from environmental/physical shocks as it does to dealing with sudden social and economic changes (including forced eviction).

Public infrastructure is another major challenge in the context of urbanisation.

'As in other regions, Asia's urban growth brings with it a host of challenges for cities and local authorities, particularly in terms of service delivery, infrastructure financing and land use. In many cities, infrastructure is failing to keep up with rapid urbanisation and the demand for services, and the brunt of these gaps generally falls on the poor, frequently in ... informal settlements'. (Sierra 2005: 29)

Smaller towns and cities often suffer from weaker financial and institutional capacity to provide public infrastructure than larger agglomerations, although the pressures of population density and competition for land can be less. More than 500 million urban dwellers lack adequate provision of water, and more than 600 million lack adequate sanitation in Asia. ${ }^{4}$ There are also very large variations in the quality and extent of water and sanitation provision. Issues include:

- inadequate quantities of water available

- infrequent or uncertain supplies of water

- cost of water/access to toilets
- contamination of water

- low-quality water

- long distances to water access points

- time taken to access water (e.g. through queuing)

The impact of inadequate access to water and sanitation include:

- health impacts of diseases (faecal-oral, waterwashed, water-based and water-related insect vector)

- reinforcing inequality and poverty (time and monetary costs of access, loss of productive/ educational time)

- reinforcing vulnerability and exclusion (e.g. among women, children, the elderly, those already suffering from ill-health or disability).

Access to water and sanitation is not solely a question of inadequate resources for investment in infrastructure in Asian cities. Provision is often related to local government capacity, and can also be linked to governance systems affected by political patronage.

Like infrastructure provision, access to services will continue to be a challenge as Asia's urban areas grow. Although national indicators for health and education tend to show that people living in urban areas are better served than their rural counterparts in most Asian countries, aggregate data is thought to mask major disparities within urban areas. Measures of proximity to basic services frequently overestimate the extent to which the urban poor actually have access to these services. High costs or other sociopolitical barriers (like being unable to register for schools or hospitals without a formally recognised address) can limit access despite proximity.

Due to the sheer numbers of people affected, tackling poverty in Asia's urban areas is vital if the Millennium Development Goals (MDGs) for poverty reduction are to be met. At the same time, the concentrated clusters of people affected by the various aspects of urban poverty described above, offer opportunities to maximise the impact and benefits of development investments. These factors are increasingly recognised:

'If the urban context of poverty is not directly addressed, it will be impossible to achieve the [Millennium Development] Goals. By improving the 


\section{Box 1 From City Development Strategy to policy and action in Phnom Penh, Cambodia}

Phnom Penh's City Development Strategy was carried out jointly by the Municipality of Phnom Penh, UN-Habitat, the Asian Coalition for Housing Rights (ACHR), the Solidarity for the Urban Poor Federation (SUPF) and the Urban Resource Centre. Research was undertaken to understand local development forces and trends as they directly affected the poorest, and results were shared among communities, academics, professionals and officials. The process of collecting and analysing information led to new working relationships, culminating in city-wide settlement planning and new models of land-sharing, voluntary resettlement and settlement upgrading carried out in accordance with the city's evolving urban development policy.

Implementation was facilitated through the Urban Poor Development Fund (UPDF), capitalised by both donors and community savings, and jointly managed by the Municipality, SUPF and ACHR. The UPDF provides loans and grants for collective income-generation schemes, housing and infrastructure developments, and other services identified by communities and government. Given the relative policy and capacity vacuums following decades of upheaval in Cambodia, the UPDF provided a forum for different groups to prioritise capital allocations and contribute non-financial resources to develop the city, and to help ensure a balance between commercial development and the needs of the urban poor. ACHR enabled exchange teams consisting of government personnel, community members, and professionals to visit Thailand and India to learn from similar experiences and to deepen working relationships.

$$
\text { Source ACHR (2003a). }
$$

lives of slum dwellers, we are also combating HIV/AIDS, improving environmental sustainability, reducing gender inequality, and addressing all the Goals in the most efficient manner. In other words, as the world becomes more urban, the integration and synergies emerging from the potential of comprehensively addressing the Goals in a specific, dense location are best achieved in the very settlements where slum dwellers live $\ldots$ by neglecting these issues, we lose the opportunity to benefit from urban growth and wealth creation ... Slum upgrading, improved urban planning and design, and the provision of adequate alternatives to new slum formation must become core business for local and national governments alike and supported by international development agencies'. (UN Millennium Project 2005b: 2)

Tackling exclusion and deprivation in urban areas will help reduce social fragmentation and the potential for political instability that can ensue. Exclusionary factor pressures concerning unequal (or uncertain) access to employment, shelter, land, basic physical infrastructure, education and health services can be exacerbated by urbanisation, leading to increased levels of violence in urban areas (Moser and Rodgers 2005). On the other hand, pro-poor urban development can greatly improve active citizenship and promote good governance (see Boxes).

\section{Addressing the challenges}

As the following subsections reveal, Asia boasts a range of cutting edge innovations in policy and practice, though more remains to be done. The challenge partly lies in scaling-up, adapting, multiplying and mainstreaming these innovations to ensure that urbanisation supports both economic development and poverty reduction.

\subsection{Urban land use}

A combination of speculation, market forces, urban beautification and large-scale infrastructure projects have made land a valuable and hotly contested commodity in Asia's urban areas, particularly in cities where urbanisation is most intense. India, Cambodia, the Philippines, Vietnam, Thailand and Indonesia all demonstrate this feature. Those living in informal slum settlements, especially the poorest, are least able to participate in the competition for land. $A$ common policy response has been, and continues to be, to forcefully evict poor communities to free-up land for these purposes, without adequate and wellplanned alternatives in place. This policy reinforces and exacerbates poverty and exclusion, and is often counterproductive and expensive in terms of managing and benefiting from urbanisation.

However, there are several examples of partnershipbased alternatives that produce win-win solutions, 


\section{Box 2 Danger zone surveys in the Philippines}

In the Philippines, as in many other countries, urbanisation is forcing poor communities to live along river banks, railway tracks, shorelines, eroded hill slopes, garbage dumps, under roads and bridges. City and national authorities do not actually know how many poor people live in such hazardous locations, or how they contribute to the city's economic and social life.

Poor communities have embarked upon 'danger zone surveys' in more than 15 cities, to plug this information gap, to stimulate community capacity building and resource mobilisation, and to show city authorities that they are serious about contributing to pro-poor city development. As a result, municipal authorities and communities are working together to find land and finance for relocation and settlement developments. Gradually, the need for affordable places for people to live and spaces for commerce is being integrated into city planning and development.

Community teams from other urban areas, together with their local government representatives, have taken part in danger zone surveys and begun to replicate the experiences in an increasing number of locations.

Source ACHR 2003b: 8-9.

benefiting towns or cities as a whole at the same time as the urban poor. Both the Urban Poor Development Fund (UPDF) in Cambodia (Box 1) and the Baan Mankong Program in Thailand (Box 4) show how governments can support city-wide and nationwide urban development programmes which incorporate land-sharing, nearby relocation and mixed developments through a partnership-based approach which actively involves those affected. In addition to incorporating these strategies into urban land use planning, governments have a role in developing a legislative environment that will ensure secure tenure for the urban poor. In the longer term, governments can address the land challenge by making provision for residential space and affordable housing in city centre locations, and in other locations close to areas of commercial activity.

\subsection{Urban infrastructure provision ${ }^{5}$}

'Cities are coping with [the challenge of financing infrastructure investments] in the midst of three major historical trends: globalization, requiring the creation of competitive infrastructure; decentralisation of responsibilities, often not matched by the delegation of authority or resources; and urbanisation requiring cities to provide basic services at an unprecedented scale'. (Sierra 2005)

Infrastructure provision continues to be a challenge in many Asian cities. Key infrastructure issues within urban areas include infrastructure financing; governance arrangements (particularly where local government capacity is low); and ensuring that infrastructure provision contributes to tackling exclusion. Support for infrastructure provision must be complemented by interventions in other sectors, if economic benefits of infrastructure investment are also to contribute to poverty reduction. There may be a trade-off between investment in infrastructure that has the greatest impact on reducing inequality and poverty within urban areas (e.g. investing in safe water, sanitation and housing), and investment in infrastructure that fosters economic linkages between urban areas and their surrounding areas (e.g. transport links, communication infrastructure). $A$ balance is clearly required, but the balance will inevitably differ between geographical areas. Mechanisms to improve integration between national and local development planning should help in determining the appropriate balance.

\subsection{Better integration between national and local development planning}

Poverty Reduction Strategy Papers (PRSPs) play an important role in determining public expenditure allocations and related donor support programmes to tackle poverty and exclusion in 14 Asian countries. ${ }^{6}$ City Development Strategies (CDSs) aim to help local authorities plan for and manage urban growth in tandem with tackling poverty and exclusion in urban areas. At present, eight ${ }^{7}$ of the 14 countries with PRSPs have also seen CDSs take place within their borders, but their PRSPs make no obvious reference 


\section{Box 3 The Community-Led Infrastructure Finance Facility (CLIFF) in India}

Launched in 2000, CLIFF is a facility providing loans, guarantees, bridge finance and technical assistance to encourage and support private sector investment in housing and infrastructure initiatives developed by organisations of the urban poor in partnership with municipal/state authorities in India. Capital is revolved to support an evolving portfolio of initiatives. The Department for International Development (DFID) provided $£ 6.84$ million, the Swedish International Development Cooperation Agency (Sida) $£ 1.5$ million and Homeless International £0.6 million to set up the facility and by June 2005, CLIFF had supported projects in five Indian cities and was scheduled to draw in revenues of more than $\mathrm{f} 25$ million, including $£ 19.2$ million from market sources.

Homeless International (2005) and Burra (2005).

to them. Given that there are often multiple agencies involved in the development, management, maintenance and future planning of Asian cities, but that greater institutional coordination is required (ACHR 2005), CDSs can be powerful tools at both local and national levels. Consideration of urban areas within their 'city-regional' context reinforces the need to promote horizontal and vertical coordination between institutions involved in city-level, national and sub-national policy formulation, because the (changing) boundaries of perceived city-regions rarely correspond with administrative boundaries (Rodríguez-Pose 2004). CDS planning provides a basis for effectively meeting the challenge of future population growth in urban areas, and needs to be included in PRSPs. It is also worth noting that some Asian countries do have a variety of urban development/urban poverty strategies and/or policies, but these do not appear to be mainstreamed in the PRSP process (ComHabitat 2005).

There are good examples in a number of countries of locally based strategies to generate accurate information about urban areas, as a basis for more effective urban planning, implementation and progress monitoring. Experiences in Phnom Penh (Box 1) and the Philippines (Box 2), for example, demonstrate that partnership-based approaches to generating information can make a positive contribution to future planning in a number of ways:

- Creation of accurate data about current spatial distributions of urban poverty, nature of deprivations and how many people are affected

- Development of practical working partnerships and institutional arrangements between communities and local/national government to address current aspects of poverty, in a manner that takes into account the need for land, infrastructure and other inputs to further economic development within cities

- Strengthening of financial mechanisms that promote partnership-based solutions to the multiple dimensions of poverty experienced in urban areas

- Development of new models of accountable, negotiation-based urban planning for future city development

- Creation of learning and interaction between cities, as a basis for replication and complementary development planning/activity.

\subsection{Access to development finance}

Access to finance, at household, settlement and city levels, is vital. At household level, microfinance already plays an important role in enabling Asian families to invest in productive activity and deal with short-term/unexpected expenditures, either linked to the formal financial sector or managed within civil society. Lack of collateral, credit records and/or more profitable alternatives for banks, mean that the urban poor can be excluded from access to finance. Credit for medium- and longer-term investments, or collective (community) investments, is however much rarer - the urban poor find it particularly difficult to access such finance. Asia demonstrates a number of innovative financial mechanisms that not only provide capital funds for medium- and long-term development investment, but also act as mechanisms to promote partnerships and collaboration. These mechanisms also help in blending and leveraging resources from a range of stakeholders. From a governance perspective, financial mechanisms can create space for collaboration and collective decision making around scarce resources, be it in relation to investment in social services, infrastructure provision, settlement improvements or income generation. 


\section{Box 4 The Community Organisations Development Institute (CODI) and the Baan Mankong Program in Thailand}

In 1992, the Thai government set up the Urban Community Development Office (UCDO) to support community organisations, with a US\$50 million capital base. This provided loans, small grants and technical support to community organisations for upgrading their homes and neighbourhoods, or developing new settlements, and for supporting microenterprises. It also supported community organisations in any city or province to join together to form a network to negotiate with city or provincial authorities, or to influence development planning, or simply to work together on shared problems of housing, livelihoods or access to basic services. UCDO increasingly provided loans to these networks rather than to the community organisations that formed the networks, with the networks managing loans to member organisations. This decentralised the decision-making process so that it was closer to individual communities and was better able to respond rapidly and flexibly to opportunities identified by network members.

In 2000, UCDO was merged with the Rural Development Fund to form the Community Organisations Development Institute (CODI), which is now implementing an ambitious national programme supporting community-led upgrading and secure tenure for urban poor households. In 2003, the programme set a target of improving housing and tenure security for 300,000 households in 2,000 poor communities in 200 Thai cities within five years. By December 2004, initiatives were under way in 175 communities, involving more than 14,600 households. But more importantly, all these initiatives were part of city-wide strategies in which urban poor organisations and their networks were involved, and which sought to ensure that all urban poor groups benefited.

The Baan Mankong Program, run by CODI, aims to solve the problem of housing insecurity in Thai cities by creating an opportunity for existing slum communities to participate actively in a local development process, whereby their settlements are upgraded, their houses are improved and their tenure is secured through a variety of terms such as long-term lease or cooperative land ownership. One of the most important aspects of how the Baan Mankong Program will be implemented is that it involves the collaboration of communities, local authorities, development agents and land owners (both public and private). The Baan Mankong Program represents a commitment by the Thai government to provide continuous support to a process whereby chronic housing and tenure security problems of the urban poor will be solved collectively within all Thai cities. By making people the core actors in the process and by using local partnership as the key strategy for solving the problems, the Baan Mankong Program is creating a collective development process and building a new model for urban development that is sustainable and equitable.

Source Adapted from Boonyabancha (2004) and ACHR on www.achr.net/bann_mankong.htm

The Community-Led Infrastructure Finance Facility (CLIFF, see Box 3) in India is interesting because it makes capital available to kick-start development initiatives created and managed by organisations of the urban poor in partnership with municipal authorities. CLIFF leverages and blends revenues from the market, government sources (e.g. subsidies) and community contributions; leverages further bridge financing from banks; and also leverages land from both the market and government. It provides financing for pro-poor developments that also improve the city as a whole, e.g. through housing developments linked to community-led relocation from land required for urban infrastructure development. CLIFF also demonstrates a way in which international donors can support communityled initiatives in multiple locations on an ongoing and sustainable basis as capital funds are revolved.

The Community Organisations Development Institute's (CODI) Baan Mankong Program in Thailand (Box 4) illustrates how government resources can be channelled through, and further enhance the capacity of, multiple community-based networks, civil society organisations at city-wide scale across numerous villages, towns and cities. The UPDF in 
Cambodia (Box 1) also demonstrates how financial mechanisms can act as a forum where communities, local authorities and other stakeholders can jointly determine a vision for a city, and contribute complementary resources towards realising this vision, in a situation where limited capacity exists within local government itself.

Decentralisation has frequently placed the responsibility for infrastructure provision upon local authorities, which have neither the resources nor always the capacity to deliver at the scale required by growing urban centres. Municipal finance is therefore a critical issue. The creation of sustainable financial structures which link urban infrastructure financing needs with domestic financial markets is considered vital in this context:

'Global experience clearly demonstrates that, with an appropriate policy and a legal and regulatory framework, cities successfully access private capita markets in order to finance urban infrastructure. Indeed, financing infrastructure in this manner also provides strong and tangible incentives for improved urban governance, efficiency and accountability ...' (Sierra 2005)

\section{Implications for governments, donors and other international agencies}

There are some common threads and 'principles' linking the examples of successful policy and/or practice to address the challenges of urbanisation and urban poverty. Governments and donors in Asia can improve their capacity to promote sustainable urbanisation allied with pro-poor growth through policy developments and alternative approaches in the following ways:

- Build on successful experiences already developed in Asia. There are numerous examples of innovative, scaleable urban development solutions which involve and benefit the urban poor, and which also support town and city development (as described above). The challenge for governments and donors is to identify, learn from, scale-up and further develop such initiatives. Donors have a role in supporting the practical exchange of ideas and experiences.

- Generate better, locally rooted, information for planning, negotiating and monitoring. The process of generating locally based information, as well as the information itself, can play a major role in developing effective, well-targeted policies and implementing them in practice. City-level information requires particular attention. National governments need to work more closely with local authorities and other local stakeholders to ensure that local/city-level information is fed into national and sub-national development strategies. Donors should consider aid modalities which support local organisations (both government and civil society) which seek to undertake such functions.

- Create genuine, long-term working partnerships which centrally involve the poor, for urban strategy development, programme planning and implementation. In particular, given trends towards decentralisation of planning responsibilities, partnerships can help supplement the comparatively weak capacity within local authorities in many parts of Asia. Governments and donors need to create 'interfaces' between formal institutions and informal sector groups, perhaps using financial mechanisms (such as the UPDF described above) to create space for this to occur. In recognition that a myriad of local and global influences affect urbanisation patterns, economic development and poverty/exclusion in urban areas, solutions need to embrace a similar range of institutions and relationships spanning local to global levels. 'Good governance' roles and relationships are most effectively negotiated and refined through joint work on practical initiatives.

- Focus upon integrated development solutions, which enable the poor to tackle the many interrelated aspects of poverty, rather than creating narrow 'sectoral' solutions. At local level, given the underlying importance of increasing real incomes, this implies a need to develop projects and programmes that particularly integrate income generation/access to credit with other strategies to improve access to services, infrastructure, land and shelter. At government-level, this implies greater collaboration between ministries in both policy development and programme implementation, particularly when considering cities in their 'city-regional' context.

- Improve regulatory frameworks to encourage participatory urban development. Governments and donors should consider how to facilitate incremental settlement upgrading. The development of nationally appropriate land registration and cadastral systems will provide a basis for the legal transfer and development of 
land; examine flexible building and planning standards to ensure affordability without compromising quality; incorporate disaster risk reduction strategies involving local communities.

- Decentralise resources and capacity to match decentralised responsibilities. National governments need to enable local authorities to access central budgetary and aid resources; donors can help examine legal frameworks to ensure local authorities can raise market finance where appropriate; and both donors and governments can play a role in ensuring regulatory frameworks enable joint initiatives between local government and civil society partners. At the same time, support for local revenue-raising mechanisms will help local authorities develop greater autonomy in policy development and implementation -

\section{Notes}

1 See Satterthwaite (2005) for a more detailed explanation.

2 There are however other political and social factors which affect rural-urban migration patterns. These include policy restrictions on movement (e.g. in Cambodia where current urbanisation arises in part from pent-up migration); international political changes (e.g. when East Pakistan became Bangladesh and people moved to Pakistan); natural disasters; and internal/nearby conflicts (e.g. Afghanistan refugees moving to Karachi).

3 Like UN-Habitat, this report uses the term 'slum' to encapsulate the wide range of low-income settlements and/or poor living conditions. It embraces the myriad of other terms used to describe settlements with poor living conditions (shanties, informal settlements, low-income settlements, shack settlements etc.). Common terms in Asia include iskwater, estero, eskinita, looban, dagat-dagatan, bedspacer, chawls/challis, ahatas, katras, bustee, zodpattis, cheris, Katchi Abadis, watta, pelpath, udukku and pelli gewal. The UN's 'operational definition' of slums, used to help formulate their statistics and projections, considered important if cities and city-regions are to become more effective units of economic development and poverty reduction.

- Improve capital financing for urban development. Develop and harness new forms of capital financing for urban development and deepen financial markets. Initiatives (including CLIFF) supported by the Private Infrastructure Development Group (PIDG - made up of DFID and its counterparts from the Netherlands, Sweden and Switzerland) offer examples and opportunities for donors in this regard. Both donors and government should particularly concentrate on the creation of sustainable financial structures which link municipal financing needs with domestic financial markets.

describes factors such as inadequate access to safe water, poor sanitation/infrastructure, poor quality housing, overcrowding, and insecure residential status. The distinctions are most important at the local level, hence the focus of this article on local strategies to address 'slums' in whatever form they are perceived and experienced in different localities. For more information about definitional issues, see UN-Habitat (2003b).

4 UN-Habitat (2003c: 14) also points out that the proportions of urban populations in Bangladesh, India, Indonesia, Myanmar, Pakistan, the Philippines, Sri Lanka and Vietnam with 'adequate' or 'safe and sufficient' water and sanitation are much lower than the proportions with 'improved' provision.

5 This article attempts to highlight some key issues with respect to the process of urbanisation.

6 Vietnam, Yemen, Cambodia, Nepal, Sri Lanka, Lao PDR, Mongolia, Pakistan, Bhutan, East Timor, Bangladesh and three in central Asia (Tajikistan, Uzbekistan, Kyrgyzstan). To read PRSPs and associated Progress reports, visit www.imf.org/external/np/prsp/prsp.asp

7 Vietnam, Yemen, Cambodia, Nepal, Sri Lanka, Mongolia, Pakistan and Bangladesh. 


\section{References}

ACHR (2005) Understanding Asian Cities, Thailand: Asian Coalition for Housing Rights, www.achr.net ACHR (2003a) Housing by People in Asia - Special Issue on Community Development Funds, Issue 14, February, Thailand: Asian Coalition for Housing Rights, www.achr.net

ACHR (2003b) Housing by People in Asia - Alternatives to Forced Eviction, Issue 15, October, Thailand: Asian Coalition for Housing Rights, www.achr.net Boonyabancha, S. (2004) 'A Decade of Change: From the Urban Community Development Office to the Community Organisation Development Institute in Thailand', in D. Satterthwaite and D. Mitlin (eds), Empowering Squatter Citizen, London: Earthscan: 25-53

Burra, S. (2005) 'Towards a Pro-poor Framework for Slum Upgrading in Mumbai, India', Environment \& Urbanization 17.1: 67-88, www.sparcindia.org/docs/sbupgrading.pdf

ComHabitat (2005) 'PRSPs, Human Settlements and Urban Poverty', paper presented to Commonwealth Finance Ministers', meeting held in Barbados, August, ComHabitat, UK, www.thecommonwealth.org/shared_asp_files/upl oadedfiles/8651EB55-5E61-4F28-8D9F85DD0A3D987C_PRSPsHumanSettsUrbanPov(F $\mathrm{MM}(05)(\mathrm{INF}) 1) \cdot \mathrm{pdf}$

DFID (2004) Slum Dwellers Factsheet, London: Department for International Development, September, www.dfid.gov.uk/pubs/files/ slumdwellers-factsheet.pdf

Gubhaju, B., Seetharam, K.S. and Huguet, J. (2001) 'Demographic Dynamics in the ESCAP Region: Implications for Sustainable Development and Poverty', Asia-Pacific Population Journal 16.1: 45-66

Homeless International (2005) Community Led Infrastructure Finance Facility (CLIFF) 3rd Annual Review, UK: Homeless International, www.homeless-international.org/cliff

Moser, C. and Rodgers, D. (2005) Change, Violence and Insecurity in Non-Conflict Situations, Working Paper 245, London: Overseas Development Institute (ODI), www.odi.org.uk/publications/ working_papers/wp245.pdf

Overman, H. and Venables, A. (2005) 'Cities in the Developing World', paper commissioned by Department for International Development (DFID), London, econ.lse.ac.uk/staff/ajv/difcit12.pdf

Rodríguez-Pose, A. (2004) 'The City-Region Approach to Economic Development', paper commissioned by Department for International Development (DFID), London

Satterthwaite, D. (2005) The Scale of Urban Change Worldwide 1950-2000 and its Underpinnings, Human Settlements Discussion Paper (Urban-01), London: International Institute for Environment and Development, May, www.iied.org/pubs/pdf/ full/9531llED.pdf

Satterthwaite, D. (2004) The Under-estimation of Urban Poverty in Low- and Middle-income Nations, Working Paper on Poverty Reduction in Urban Areas 14, London: International Institute for Environment and Development, www.iied.org/ pubs/pdf/full/9322IIED.pdf

Satterthwaite, D. (2002) Reducing Urban Poverty; Some Lessons from Experience, Working Paper on Poverty Reduction in Urban Areas 2, London: International Institute for Environment and Development, www.iied.org/pubs/pdf/full/ 9155llED.pdf

Sierra, K. (2005) 'Financing City Infrastructure', Villes en Developpement 69 (September), Paris: Cities Alliance/ISTED, www.citiesalliance.org/doc/ resources/financing/ved_no-69 per cent20_eng.pdf

UN-Habitat (2005) Global Urban Observatory Human Settlements Statistics Database, Nairobi, Kenya: UN-Habitat, www.unhabitat.org/programmes/ guo/data_hsdb4.asp

UN-Habitat (2004) 'State of the World's Cities: Trends in Asia and the Pacific', UN-Habitat Press Release, Nairobi, Kenya, September, www.unhabitat.org/ mediacentre/documents/sowc/RegionalAsia.pdf

UN-Habitat (2003a) Total, Urban and Estimated Slum Population by Major Region, 2001, UN-Habitat Press Release, Nairobi, Kenya, October, www.unhabitat.org/mediacentre/documents/ whd/GRHSB6.pdf

UN-Habitat (2003b) The Challenge of Slums: Global Report on Human Settlements, London: Earthscan

UN-Habitat (2003c) Water and Sanitation in the World's Cities: Local Action for Global Goals, London: Earthscan

UN Millennium Project (2005a) Investing in Development: A Practical Plan to Achieve the Millennium Development Goals, known as the Sachs Report, New York: United Nations Development Programme, www.unmillenniumproject.org/ reports/fullreport.htm

UN Millennium Project (2005b) A Home in the City: The Report of the Task Force on Improving the Lives of Slum Dwellers, London: Earthscan, www.unmillenniumproject.org/documents/ Slumdwellers-complete.pdf 
UN Population Division (2002) World Urbanization Prospects: The 2001 Revision, New York: United Nations Department of Economic and Social Affairs Population Division, www.un.org/esa/ population/publications/wup2001/ WUP2001report.htm

Webster, D. (2004) Urbanization Dynamics and Policy Frameworks in Developing East Asia, World Bank
East Asia Infrastructure Department's Working Paper 8, Washington DC: World Bank, http://siteresources.worldbank.org/INTEAPREGT OPURBDEV/Resources/Urbanization-Dynamics2004.pdf 